Шестопалова Т. П. доктор філологічних наук,професор Д3 «Луганський наиіональний університет імені Тараса Шевченка»

\title{
ШЕВЧЕНКОЗНАВЧІ СТУДІЇ ЮРІЯ ЛАВРІНЕНКА
}

Статтю присвячено маловідомій шевченкознавчій проблематичі письменницького доробку Ю. Лавріненка, в якому категорії любові й кордочентризму трактуються як творчі, морально-етичні, структурно-семіотичні чентри поезії й життя Т. Шевченка.

Ключові слова: Т. Шевченко, П. Куліш, М. Драгоманов, І. Франко, кордоцентризм.

Статья посвящена малоизвестной шевченковедческой проблематике писательского наследия Ю. Лавриненко. Он рассматривал категории любви и кордочентризма в качестве творческих, морально-этических, структурносемиотических центров поэзии и жизни Т. Шевченко.

Ключевые слова: Т. Шевченко, П. Кулиш, М. Драгоманов, И. Франко, кордочентризм.

The article is devoted to unknown page of J. Lawrynenko's scientific legacy Shevchenko's theme. Lawrynenko examined the category of love and kordocentryzm as a creative, ethic, structural-semiotics center of poetry and all life of T. Shevchenko.

Key words: T. Shevchenko, P. Kulish, M. Drahomanov, I. Franko, a cordocentrysm.

Шевченкознавчі праці Ю. Лавріненка становлять один із маловідомих аспектів його літературознавчої діяльності. На сьогодні він репрезентований рукописом «Шевченків Рубікон» [Лавріненко 38/3], де розкрито чинники появи та значення поезії «трьох літ» (1843-1845 pр.), англомовною студією «Шевченко й "Кобзар" в інтелектуальній та політичній історії століття» [Lawrynenko 1962], есеєм «Любов - формотворча вісь Шевченкової поетичної синтези» [Лавріненко 1962], а також епістолярними матеріалами. Вивчення названих студій становить додаткову перспективу для вивчення й інтерпретації модерного канону української культури. Ю. Лавріненкові близький погляд на «духову панораму» українсь- 
кого суспільства XIX та XX століть крізь призму літературного досвіду нації.

«Шевченкова сага та їі герої» - одна 3 перших, істинно «лавріненківських», назв роботи, яку в остаточному варіанті змінила науково-нейтральна - «Шевченко й "Кобзар" в інтелектуальній та політичній історії століття». Попри те, що метафора «саги» зазнала критики [Петренко 8/2-3], вона цілком точно відбивала стиль мислення автора та концепцію представленого ним історичного періоду. «Коли помер поет - народився святий» [Lawrynenko 1962: 155], зрезюмував біографічний вступ про поета («історію героя») Ю. Лавріненко. Легенда про поета-святого, крім нього самого, має інших персонажів. П. Куліш (1819-1897рр.) («хто найперше чувся відповідальним за ї̈ народження й популяризаџію», «названий брат, який посвідчив його тріумфи й агонію» [Lawrynenko 1962: 155]), М. Драгоманов (1841-1895 рр.) («духовний син <..> західної позитивістсько-рачіоналістсько-сочіалістичної ідеологї̈», «був Кулішевим антагоністом, проте інкорпорував до свойх пізніших прачь сформульовані Кулімем ідеї» [Lawrynenko 1962: 156]), I. Франко (1856-1916 pp.) («послідовник Драгоманова, який напружено боровся та зрештою переміг потужний вплив свого наставника» [Lawrynenko 1962: 156] та «Шевченкові люди», що «навіть не спробували прийти до критичної дефініції поетичної синтези "Кобзаря"», хоча вона «відбивала їхні найяскравіші можливості та найнижчі слабкості» [Lawrynenko 1962: 157-158] - таким Ю. Лавріненко вимальовує профіль (чи «контур») «Шевченкової саги», головний герой якої тримав у собі «непереможну силу» мистецького духу, що виявився як «свята поезія», «жива посмішка мистецтва» та «поезія як думка» [Lawrynenko 1962: 159].

Усі три аспекти відбивають індивідуальний характер поезії Шевченка - «емочійно спрощеної, але ускладненої інтелектуальною когнічією "Кобзаря"» [Lawrynenko 1962: 159]. «Свята поезія» промовляє молитовними, прохальними, псаломними мотивами та ритмами Шевченкових творів, образами досконалої, класичної 
краси та гармонії, а також бароковим вибухом пророчого гніву та «смертельного сарказму», що призводить до «відчайдушної суперечки з Богом» [Lawrynenko 1962: 159]. «Жива посмішка мистецтва» в «Кобзарі» становить, на думку Ю. Лавріненка, найменш помічений читачами його план. «Поезія як гра, як "вибрик" того надвишку життьової сили, що є в людині попри всі виснажливі витрати на повсякчасну боротьбу за голе існування $і$ життьову позицію» [Лавріненко 38/4-7], - є, на думку автора студії, рисою не менш характерною для поета, ніж месіанська та мученицька. Саме артистичне, ігрове, перевтілювальне начало зумовлює безкінечне шевченківське «відчуття свободи як передумови життя, росту, творчости як толеранції, $і$ як божественного основного закону світобудови - "світу вольного, несповитого" (так, наче Шевченко мислив категоріями модерної квантової фізики, а не старої Ньютонової)» [Лавріненко 38/4-7].

«Поезія як думка» в мистецькому космосі «Кобзаря» зумовлена синтезом духовного благоговіння перед світом і Богом («свята поезія») та аксіологічно наснаженою внутрішньою свободою. «Думка» як поетична фактура й жанр його творів, «думи», що прокладають шлях від серця (почуттєвої сфери) до розуму (інтелекту), створюють простір сконденсованої мисленнєвої дії, котра переносить читача в простір полівалентних сутностей, найкраще означуваний афористичними рядками та строфами Шевченка. Ю. Лавріненко пише: «Мудрість Шевченка не може бути осягнута простим нагромадженням фактів, зібранням очевидностей або механічним поєднанням складових основних джерел; радше ие здатність синтезувати почуття й думку, старе й нове», котра виявляє в Шевченкових образах «свідомого артиста з повно розвиненим критичним сприйняттям» [Lawrynenko 1962: 163-164].

Чільна прикмета поетичного характеру Шевченка, за Ю. Лавріненком, що сугерується з усіх трьох сторін його поетичного генія, лежить у його особливому «безтурботно-доброму» й любовному ставленні до життя, рослин і тварин, найперше, «до конкретної 
людини, ї̈ щастя й болю» [Lawrynenko 1962: 162]. Не можна не побачити, що критик провадить розмову про антропологічне осердя творчості поета: «...деякі дослідники (насамперед Лавріненкові йдеться про Д. Чижевського. - Т. Ш.) Шевченка вбачають чентром його філософії антропологізм» [Lawrynenko 1962: 162]. Сам Ю. Лавріненко доводить цю думку до певного заперечення - через категорію любові як головного чинника появи та існування Шевченкового поетичного стилю (це наголошено в статті «Любов формотворча вісь Шевченкової поетичної синтези»). Свропейськість Шевченка, провадив літературознавець, полягає в належності митця до європейської філософської традиції, у якій любов «має онтологічне значення, первісно-творче, структуральне, конкретне $i$ метафізичне разом» [Лавріненко 1962: 3-10]. Однак те, що «Кобзар» звернений в майбутнє, а не в минуле («книжка проспективна, а не ретроспективна»), змушує вирізнити в цій традиції актуальні для розуміння Шевченкової категорії любові позиції, оскільки сама традиція на історичному шляху розвитку об'єднала протилежні погляди.

Зокрема, вважає дослідник, поетичній синтезі чужа платонівська ідея любові, яка «сконцепчійована не проспективно, а ретроспективно, вона рухає назад - до "досконалого" $i$ "єдиного" первісного» [Лавріненко 1962: 7]. Натомість «Кобзар» акумулює в собі ту, що М. Шелер сформулював як «любляче сходження вищого до нижчого, Бога до людей, святого до грішника і т. д. Любов включена в суть "вищого", а також $i$ "найвищого", тобто в Бога» [Лавріненко 1962: 8]. Саме цей філософ пояснив значення любові для сприйняття світу в його повноті й розмаїтті, вказавши, що через неї як «зацікавлення», «симпатизуючу участь» відбувається не лише «особисте охоплення й пізнання світу - самі пізнані речі приходять у їхньому самооб'явленні до їхнього повного буття $i$ вартости» [Лавріненко 1962: 8].

Методологічну можливість дослідити спосіб поетичного мислення Кобзаря Ю. Лавріненко бачить у прикладанні кордоцентризму 
як національної традиції мислення до осягнення стильового синтезу поезії Т. Шевченка: «"Любов" стала формотворчою віссю $i$ поетичного стилю Шевченка. I мірою того як у поета визрівало явище творчої любови, його стиль набирав більшої оригінальности $i$ вивершення. Трудно його припасувати до "романтизму", ще трудніме до "реалізму" чи іншого якого "ізму". Шевченків стиль - явище не похідне, а само собі фундуюче, явище якоїсь синтези» [Лавріненко 1962: 9]. Така критична інтенція природи стильового синтезу в Шевченковому космопсихологосі сьогодні сприймається як когерентне актуальним методологічним рухам явище, оскільки саме поняття вісі, котра прямовисно проходить крізь певне завузлення горизонтальної площини поезії, водночас зумовлюючи його собою, знаходить собі теоретико-понятійні аналогії та описи в таких цілком продуктивних на сьогодні підходах, що репрезентовані працями М. Мамардашвілі [Мамардашвили 2000: 104, 368].

Поза тим теза про синтетичний характер поетики Шевченка, сформульована Ю. Лавріненком, народилася та по-своєму оформилася в аналітичному мисленні Л. Плюща, коли він «крізь n'ятірну "пару окулярів" - юнгівських, леві-стросівських, бахтінських, лотманівських, топоровсько-івановських» [Забужко 1997: 35] розібрав «Москалеву криницю», у критичній свідомості Б. Рубчака, котрий по-новому відкривав поета, «навпереміну граючи то екзистенціалістськими, то феноменологічними, то герменевтичними, то "новокритичними" інструментами $і$ в такий спосіб немовби імітуючи й відтворюючи власну Шевченкову "зміну масок" ...» [Забужко 1997: 35]. Ю. Лавріненко свого часу відчув і вказав на необхідність синтетичного підходу до Шевченкової поезії, сформулювавши тезу про інтенцію Шевченкової любові як творчого, морально-етичного, структурно-семіотичного центру його поезії.

Романтична «філософія серця» об'єднує з Т. Шевченком П. Куліша. Хоч «темперамент та їхня тактика» надто різнилися [Lawrynenko 1962: 174], усе ж саме з огляду на ментальну вкоріненість у свідомість обох сучасників почуття любові як онтологічної 
ймовірності наближення людини в ії миследії до Абсолюту якраз через те, що вона і те, що вона робить, - неідеальне, Ю. Лавріненко виводить принципову, на його думку, лінію взаємовпливу цих двох героїв саги. ІІї зміст полягає в тому, що П. Куліш, який мав раціональний спосіб мислення, прагнув захистити «святий поклик до свободи» в «Кобзарі» від перетворення на «заклик до повстання, у якому безконтрольний спонтанний тип украйния <...> зазнає втрати громадської самодисципліни та конструктивних зусиль щодо національної й політичної незалежності» [Lawrynenko 1962: 174]. Відповідний проект мав зреалізувати журнал «Основа», який так недовго проіснував під тиском антиукраїнських законів Російської імперії. «Так дім, який Куліш так копітко будував із Кобзарем, перетворився на руїни» [Lawrynenko 1962: 179], - зрезюмував частину своєї праці Ю. Лавріненко.

Після смерті поета П. Куліш зайняв різко критичну позицію, яку більшість сучасників і наступників оцінили як повстання проти Шевченка й усього, що той створив. Ю. Лавріненко з перспективи категорії любові потрактував позицію П. Куліша як свідчення глибокої внутрішньої спорідненості обох особистостей. Зокрема автор «Чорної ради» поставив питання про причини «політичного убозтва України» попри те, що ії новий ренесанс був практично визначений «Кобзарем» - книгою, яка так легко ввійшла до свідомості найширших українських національних кіл. Відтак, саме для того, щоб знайти причини «іррачіональної темряви історичної ситуачії свого часу», П. Куліш мусив дистанціюватися й від «Кобзаря», й від його автора, аби об'єктивно проаналізувати поразку, якою обернулося інспіроване Шевченковою поезією нове українське відродження [Lawrynenko 1962: 183].

Цей аналіз виходив поза межі власне науково-літературознавчого, потребував для себе даних історичних та політологічних. На їхньому тлі Шевченко перетворювався на чинник амбівалентних і драматичних суспільно-інтелектуальних процесів другої половини XIX ст., коли ідея справедливої революції змінилася на ідола про- 
гресу, заради якого здійснювалися марні спроби прищепити російські та західні форми соціалізму на український грунт. «Культ Шевченка та козаччини так чи так став частиною цього потужного руху», - доводив Ю. Лавріненко. Це й лягло в основу Кулішевих атак на Шевченка [Lawrynenko 1962: 185], у яких заатакованими слід розуміти не поезію, не козаччину, не ідею революції, а «антикультурний культ Шевченка», «антиісторичний культ козаччини», «антиполітичний культ револючї̈» [Lawrynenko 1962: 187]. Відтак, болісний критицизм Шевченка Кулішем несе в собі глибшу повагу й любов до поета, ніж емоційне й безкритичне прославляння цього останнього та інспірованих ним культів з боку багатьох інших прихильників.

Характерним для критичної манери Ю. Лавріненка $є$ підсумок щодо взаємин Шевченка й Куліша: «У Шевченкові ми знаходимо біль багатовікового пригнічення Украӥни, у той час Куліш забезпечує нас сумлінною картиною історії та діагностує ї. $У$ Шевченкові ми маємо апофеоз верховної свободи; у Кулімеві апофеоз конструктивної самодисиипліни. У Шевченкові маємо енергію ліричної спонтанності "серия"; у Кулішеві - енергію "конструктивного розуму". Обоє друзів дивилися вниз у ту жс саму безодню та - вгору - у те ж саме небо; для обох любов та ствердження життя вражалися ненавистю та негачісю життя. Але поки поет збирався переступити чю прірву на крилах поезії, мислитель $і$ політик осягав ї прямовисну глибину $i$, щоб сходити ї крутими стінами, обережно перевіряв кожен камінь. Це не просто, і иіна, яку заплатив Куліш, - самотність та близькість до саморуйнаиії - не є дешевою» [Lawrynenko 1962: 191].

Творчий доробок П. Куліша зумовлений Шевченковим гені$€ м$ - ця теза становить для Ю. Лавріненка важливе свідчення драми глибинної єдності обох героїв: власні поетичні твори Куліша «органічно співвідносяться з синтезою "Кобзаря", ніби з якимось унікальним архітектурно-філософським планом» [Lawrynenko 1962: 215]. Куліш відніс Шевченка до плеяди духовних батьків 
разом із Бояном, І. Вишенським, Й. Борецьким, Г. Сковородою; сприйняв Шевченкові варіації на біблійні теми як заповіт здійснити перший в Україні переклад Біблії та багато іншого. «Куліш відкрив свою власну книжку "Позичена кобза" поемами, які презентували Шевченка як поета, що виніс украӥнську мову на високий рівень літератури старого Києва, у розумінні Куліша, та на високий рівень Західної поезії. Куліш розглянув свої переклади виключно як втілення досягнень Шевченкового генія, втілення не менш значне, ніж європеїзаиія Украӥни. Це логічне завершення Кулішевої війни проти тих, хто паразитував на Шевченковому культі. Усі випадкові події, всупереч злості, нерозумінню щоденних моментів, представляють нам Кулішеве досягнення - його рачіональний внесок у поетичну синтезу Шевченка» [Lawrynenko 1962: 217], - підсумував автор розвідки.

Частина про наступного героя саги - М. Драгоманова - має характеристичну назву: «"Кобзар" у "війні терору" 1870-1880 років та Драгоманов» [Lawrynenko 1962: 194]. На думку Ю. Лавріненка, М. Драгоманов одразу став на шлях, уторований П. Кулішем, критики культу Шевченка, - але, водночас, пішов далі, до негації самої творчості: «Якщо Куліш намагався вберегти Шевченка від шкідливого культу, то Драгоманов зробив спробу принизити не лише культ, але й самого поета» [Lawrynenko 1962: 196]. Протилежно Ю. Лавріненкові Г. Грабович назвав М. Драгоманова наступником П. Куліша в боротьбі з культом Т. Шевченка [Грабович 1991: 9]. Ніби застерігаючи на майбутнє від такого об'єднання двох цілковито різних за ставленням до Шевченка особистостей, Ю. Лавріненко зазначає, що фундаментальна основа поетового мистецтва, яка утримує «магнетичне поле любові й ненависті, примирення й повстання», для Драгоманова була тільки вислідом недостатньої освіти та відсутності «знайомства з науковорачіоналістичними поглядами». Цим пояснювалося, що політикраціоналіст відводив Шевченкові роль «новонаверненого до партійної лінії радикально-сочіалістичної доктрини» й не бачив його 
серед вирішальних чинників «довготривалої руїни в Україні та в иілій Східній Європі» [Lawrynenko 1962: 196].

Головною причиною неприйняття світогляду одного інтелектуала іншим були відмінні вихідні позиції їхнього мислення. Поет поклав в основу свого світовідчуття «концепцію трагічного як базового елементу в структурі універсуму», політик європейського штибу вибрав «одну й лиш одну провідну нитку непогрішимого людського прогресу», «колективної економіки», «царство розуму», у якому не було місця катаклізмам, що нестиме в світ нове століття, - узагальнив Ю. Лавріненко [Lawrynenko 1962: 203]. Водночас наприкінці життя М. Драгоманов підійшов до усвідомлення вищого значення Шевченка в житті українців та України: «B "Автобіографії" він зазначив, щео й найбільш освічені з украйнців далекі від того, щзоб іти в ногу з Шевченком» [Lawrynenko 1962: 205]. Маючи на меті реформи в цілій Росії на принципах свободи й демократії, М. Драгоманов віднайшов грунт для себе в діяльності Кирило-Мефодіївського братства. Крім того, 1891 р. ідею Братства він оцінив як наймудрішу 3 тих, що дали українські патріоти, а 1894 р. назвав Шевченка генієм і зауважив, що його національна свідомість і любов $є$ епохальним феноменом історії та соціологічного мислення в Україні.

Коли спробувати вирізнити теоретичні зазернення думки Ю. Лавріненка, то на першому плані тут, безумовно, стоїть опірнозаперечувальна реакція на монопольні засяги марксистської соціології в літературознавстві. Вона відбилася ще в лекціях для ДіПіпоселенців «Потерчата української духовности» та «Епоха раціоналізму. Драгоманівські покоління», у яких Лавріненко прокреслював сильні та слабкі боки цієї методології, відомі йому не лише 3 книжок, а й із власного життєвого досвіду. Зокрема, він визнавав неперехідну роль раціоналіста й соціаліста Драгоманова у виведенні українців «на бурхливі й широкі води політичної боротьби й організачії» [Лавріненко 44/8: 4], але й показував, що політик «наче не добачав того, що світовий людський рух не є щось абсолютне $i$ первозданне, а похідне від групових начіональних рухів, щю "всесвітня 
правда" с не що інше, як співвідношення правд начіональних, індивідуальних» [Лавріненко 44/8: 8].

Драгоманівське покоління відмовилося від культури «глибокого серия» [Лавріненко 44/10: 5], відтак, не набуло «глибокого синтетичного підходу» до життя й мистецтва [Лавріненко 44/8: 1]. «Культура глибокого серця» не має нічого спільного з плаксивістю та поверховою перечуленістю, що від якогось часу заполонили українську літературу. Авторові цих студій ідеться про «велике "серче", яке ми бачимо в Шевченковім Гонті і Гамалії, в Шевченковій Марії, в гоголівськім Тарасі, в козауькім епосі, в "Слові о полку" і навіть у матріярхальній культурі трипільців. Тут треба було іти на глибинах недокінченої прачі Сковороди і Юркевича, яку абсолютно не було кому продовжувати серед драгоманівців. Tе "серие", та ще озброєне драгоманівським розумом і світовим кругозором, побачило б багато важливих речей, якими клекотало украӥнське життя на межі двох століть $і$ які вирвались назверх 1917 року (примітка олівцем: "1917 p. був проти Сковороди і Юркевича, так само як в Росії проти аналогічних Достоєвського $i$ Соловйова". - Т. Ш.)» [Лавріненко 44/10: 4].

I тут ми бачимо, що Ю. Лавріненко цілком не відкидає тези, звично прив'язуваної до марксизму, про заангажованість літератури. Навпаки, ця остання може існувати тільки історично, у сув'язі завдань та обов'язків сучасного суспільства, де вона народжується й живе. Щоправда, ці «завдання» й «обов'язки» не трактуються дослідником у плані економічної ситуації, політичної кон'юнктури, ідеологічних гасел тощо. Заангажованість літератури передусім визначається прагненням митця та його читачів висловити власну свідомість дійсності з усіма припущеннями, уявленнями, сподіваннями, розчаруваннями тощо щодо неї, що загально й можуть бути виражені як «культура серця». Куліш обстоював у Шевченкові небачену доти в українській поезії силу внутрішнього почуття людини, що трактує свободу в якості головної політичної, естетичної, екзистенційної цінності, усім своїм єством репрезентує 
іï як волю та здатність особи брати гору над власними недотягненнями, пристрастями, вадами сумління, соціальною, національною несправедливістю. Драгоманова відштовхувала від Шевченка відданість останнього вже ніби зужитим цінностям - людині, родині, релігії - у той час, коли прогрес став ототожнюватися з атеїзмом, соціальною рівністю, науково-економічним злетом. Як писав Ю. Лавріненко, «йому [Драгоманову. - Т. Ш.] не вдалося зрозуміти Шевченкову палку любов до людей, до свободи, краси життя, та його відчайдушний погляд на нездатність людини й суспільства реалізувати свої можливості» [Lawrynenko 1962: 203], хоча, зрештою, він визнав, що поет становить цілу епоху національної історії та культури. Ю. Лавріненко схиляє думати, що компетенція людського серця творить у мистецькому просторі коли не осібне, то виразне на тлі іншого, поле заангажованості людського в людське в тому сенсі, як це розумів Ж.-П. Сартр у студії «Що таке література?» [Сартр 2000].

Французький філософ вважав, що поява художнього твору говорить про усвідомлену митцем необхідність «і розкривати світ, і водночас пропонувати його як тягар для великодушності читача. Це значить, використовувати чужу свідомість, щоби домогтися свого лідерства в сукупності буття. Значить, хотіти, щоб ие лідерство було втілене в життя через посередників. $A$ з другого боку, реальний світ розкривається тільки перед дією, і почути себе можна, тільки зробивии крок назустріч з метою його змінити» [Сартр 2000: 9]. Ані читач, ані письменник не в силі звільнитися від історичності власного світу, який постійно присутній у їхніх судженнях та оцінках, але спільного простору вони досягають не тоді, коли перебувають у спільному часі чи дотримуються схожих поглядів на життя, а коли бачать один в одному можливість зануритися (бути заангажованими) в актуальні ідеологічні, естетичні, морально-етичні цінності, які складають основу людини як екзистенційного проекту. Власне, Лавріненкова «сага» відкриває панораму української дійсності XIX століття крізь призму чотирьох індиві- 
дуальних літературних (у широкому значенні) проектів, що не могли бути реалізовані поза відповідними героями. Історія, політика, література взаємозумовлені й пов'язані між собою в полівалентному просторі потужно аксіологізованого людського буття, відтак, вони мають людське обличчя, а дійсне уявлення про них дає думка та вчинок конкретної людини за певних обставин (лише нагадаємо, що 1957 р. Ю. Лавріненко вже апробував подібний підхід при написанні есе «Література межової ситуації»).

Історія I. Франка є синтезуючим компонентом Лавріненкової шевченкознавчої розвідки, що зримо містить у собі теоретичні інтенції названої праці Ж.-П. Сарта та інші. І. Франко - поет посідав друге після Шевченка місце, а як прозаїк та український енциклопедист - друге після Куліша. Однак від студентських років він зазнав найбільшого впливу з боку М. Драгоманова: «ставлячи себе поряд із Драгомановим проти Шевченка й Куліма, Франко втягнув себе у конфлікт, що викликав у ньому відгук психологічно, естетично, ідеологічно й політично» [Lawrynenko 1962: 218]. Однак сам дослідник був схильний тлумачити його не в синхронній сукупності всіх його проявів / аспектів, а як екзистенційну драму 3 почерговим розгортанням іï частин. Початок лежить у колізіях особистого життя молодого І. Франка, пов'язаних з О. Рошкевич, оскільки вони вперше чітко показали, що молодий поет-суспільник політичну догму поставив вище коханої жінки.

Цей вибір слід вважати одночасно й перемогою й початком поразки Драгоманова в житті й творчій діяльності І. Франка, оскільки паралельно до колосальної праці, здійснюваної в напрямку введення Шевченкових творів до масиву громадської революційної боротьби (характерними з цієї точки зору є «Причинки до оцінки творів Тараса Шевченка»), зростала внутрішня (неполітична) потреба в Шевченкові. Ю. Лавріненко пише, що родинно-інтимний світ Франка - його матері та нареченої Ольги - був частиною Шевченкового світу [Lawrynenko 1962: 225], і це наперед визначило його глибокий літературознавчий інтерес до жіночої теми в Шев- 
ченковому доробку. Зокрема, пишучи статтю «Женщина-мати» (1876 p.), І. Франко, хоч і міцно пов'язаний зі своїм тодішнім політичним образом, «зробив величезний стрибок від Драгоманова» [Lawrynenko 1962: 225], показав Україну як любов, що визначає людину в Шевченковому космосі. Коли ж говорити про таку відому працю, як «Причинки до оцінки творів Тараса Шевченка» (1881 р.), то тут твердо надано перевагу суспільному аспекту Шевченкових творів, а не мистецькому чи філософському [Lawrynenko 1962: 228-229].

Ю. Лавріненко вважає описаний підхід характерним для Франка-критика Шевченкового спадку до 1886 р. Однак те, що 3 1883 по 1885 рр. він не писав поезії, може свідчити про сумніви й біль, пережиті ним у цей період і пов'язані з Шевченковим ім'ям. Зрештою, «у наступні роки, 1886-1898, Франко постав супроти самого себе, супроти позитивізму й сочіалізму. Поет і мислитель шукав певного контакту з Шевченком. <..> Того ж року Франко написав "Ідилію", де в дивний спосіб він поєднав в одну картину своє та Шевченкове дитинство. <..> I того ж самого року Франко почав писати свій ліричний иүкл під назвою "Зів 'яле листя". <..> Не перериваючи чієї роботи, він написав "Смерть Каїна" в 1889 рочі. Ця довга поема є віхою у Франковому духовному розвитку. <..> Кайн заповнений братньою любов ю. Знання, ідол позитивістського соціалізму, перетворилося на простий інструмент. Значення було тепер надано вищим иінностям: любові, красі, добру» [Lawrynenko 1962: 231-232].

Із цього моменту дослідження Ю. Лавріненко прагне показати, як Франкове сприйняття літератури сполучало раціоналістичні та ідеалістичні начала його світогляду. Останні стверджували роль духовного серия, живого, не пояснюваного в межах раціоналістичного світогляду, дійсного чуття людини в літературі та способах іï сприйняття. Літературознавець вважає, що «вплив Шевченка полягав не в тому, що Франко з "послідовників Драгоманова" перетворився на "обожнювача Шевченка", але в тому, що Франко став 
собою, як Шевченко був собою. <..> Суб 'єктивність духовного "серия" довела більшу "об 'єктивність", ніж програмовий об 'єктивізм реалізму» [Lawrynenko 1962: 241]. 1906-1908 рр. так само засвідчили прагнення Франка погодити в собі дві - усвідомлені як драгоманівська та шевченківська - ідентичності, оскільки він паралельно займався виданням листів М. Драгоманова до себе й інших і готував до друку двотомник Шевченкових творів. «Франко часто звертав увагу, що він не був генісм, який може подолати ірраціональність людського раціоналізму» [Lawrynenko 1962: 235]. Через це у своїй величній поемі «Мойсей» Франко показав відсутність вирішення його внутрішнього конфлікту й просто перерахував акти власної духовної драми, показавши в образі Мойсея уявну конфронтацію між Т. Шевченком і М. Драгомановим [Lawrynenko 1962: 247].

Багато зрілих Франкових шевченкознавчих статей свідчать про постановку ним у центр критичної свідомості питання про поетичний синтез художнього твору, а не політичної доктрини. «Перебендя», «Тополя», «Наймичка», «Марія» - твори, які надихнули його усвідомити й критично оцінити власну драму: драму митця, котрий болісно змагався між власною музою та громадянським обов'язком, батька «ненароджених дітей» - віршів, відданих в офіру «розуму» й «загальному прогресу». Його власні поеми «Похорон», «Іван Вишенський», «Зів'яле листя» явили поета, що ставився до мистецтва 3 великою пристрастю й подивуванням, яке здатен вмістити тільки первень людського серця, а водночас глибоко усвідомлював розтрату свого поетичного таланту на шляху до опанування новопосталих суспільних ідеалів. У циклі «Із книги Кааф», як пише Ю. Лавріненко, ця сама тема втраченого поетичного таланту відтворилася в своїх політичних аспектах. Тут Франко, ніби в історичному диспуті між Шевченком та Драгомановим, дав більш значущі сторони «серця», навіть контрасти «серця», яке все вбирає, й однобокого «розуму».

Зрештою, наскільки концептуальним для Франка було прийняття Шевченкового генія «глибокого серця», показує «Нарис 
історії української літератури до 1890 року» та суспільствознавчий нарис «Молода Україна», де відповідно історик літератури й політик поставив на перше місце Т. Шевченка, а на друге - П. Куліша [Lawrynenko 1962: 250]. А тим, хто, на думку Ю. Лавріненка, й наступному столітті гідно перейняв «вісь Шевченкової поезї» й зумів вивести «з бруду примітивного захоплення» й відродити «поетичну синтезу всеобіймаючого, иирокого "серия"» [Lawrynenko 1962: 257], був П. Тичина 3 його оригінальним кларнетичним естетичним чуттям.

Таким чином, ми бачимо спробу показати український літературний канон XIX ст. в його комплексній та інтердисциплінарній перспективі. Література постає явищем заангажованим, глибоко й розмаїто пов'язаним з іншими контекстами людської дійсності. Єдиним способом перевірки іiі життєздатності й продуктивності була й лишається безпосередня критична рецепція, у ході якої вона не сприймається ізольовано від інших форм духовної та практичної діяльності, становить один із аспектів реалізації людини як екзистенційного, естетичного, прагматичного, риторичного тощо проектів. Розкривши етапне значення Т. Шевченка, П. Куліша, М. Драгоманова, І. Франка в комплексі ідей національного культурного розвитку модерної доби та увівши їх до складу свого дослідницького сюжету, Ю. Лавріненко провадив думку до естетико-культурологічної проблематики, що була покликана віднайти спільну опцію творчо-інтелектуальних зусиль цілком відмінних особистостей. Він окреслив ії як духовне серце, любов, що наймогутніше виявилася в життєвій і творчій поставі Т. Шевченка, а далі визначила собою рух естетичної, культурологічної, політичної свідомості цілого XIX ст., перейшовши звідти у XX ст.

\section{БІБЛІОГРАФІЯ}

Грабович 1991 - Грабович Г. Шевченко як міфотворець / Григорій Грабович. - К. : Рад. письм., 1991. - 210 с.

Забужко 1997 - Забужко О. Шевченків міф України / Оксана Забужко. - К. : Абрис, 1997. $-144 \mathrm{c}$. 
Лавріненко 44/8 - Лавріненко Ю. Епоха раціоналізму. Драгоманівські покоління : рукопис / Юрій Лавріненко // Jurij Lawrynenko Papers. - Series V: Writings. Subseries 8: Lectures given in 1945 in Displaced Persons' Camps, Germany, on «Ukrains'ka inteligentsiia v borot'bi za dukhove samovyznachennia» (holograph notes, drafts, typescripts). - Box 44, folder 8. - Rare Book \& Manuscript Library of Columbia University Butler Library.

Лавріненко 1962 - Лавріненко Ю. Любов - формотворча вісь Шевченкової поетичної синтези / Юрій Лавріненко // Листи до приятелів. - 1962. - Кн. 3-4. - С. 3-10.

Лавріненко 44/10 - Лавріненко Ю. Потерчата української духовности : рукопис / Юрій Лавріненко // Jurij Lawrynenko Papers. - Series V: Writings. - Subseries 8: Lectures given in 1945 in Displaced Persons' Camps, Germany, on «Ukrains'ka inteligentsiia v borot'bi za dukhove samovyznachennia» (holograph notes, drafts, typescripts). - Box 44, folder 10. - Rare Book \& Manuscript Library of Columbia University Butler Library.

Лавріненко 38/3 - Лавріненко Ю. Шевченків Рубікон : рукопис / Юрій Лавріненко // Jurij Lawrynenko Papers. - Series V: Writings. - Subseries 5: Major Literary Studies. - Box 38, folder 3. - Rare Book \& Manuscript Library of Columbia University Butler Library.

Лавріненко 38/4-7 - Лавріненко Ю. Шевченкова сага і їі герої : рукопис / Юрій Лавріненко // Jurij Lawrynenko Papers. - Series V: Writings. - Subseries 5: Major Literary Studies. - Box 38, folder 4-7. - Rare Book \& Manuscript Library of Columbia University Butler Library.

Мамардашвили 2000 - Мамардашвили М. Эстетика мышления / Мераб Мамардашвили. - М. : Моск. пाк. полит. исслед., 2000. - 416 с.

Петренко 8/2-3 - Петренко П. Лист до Ю. Лавріненка від 20.8.1961 р. / Павло Петренко // Jurij Lawrynenko Papers. - Series I: Correspondence. - Subseries 1: Correspondence with Individuals. - Box 8, folder 2-3. - Rare Book \& Manuscript Library of Columbia University Butler Library.

Сартр 2000 - Сартр Ж. П. Что такое литература? / Жан Поль Сартр ; [пер. Н.И. Полторацкой]. - СПб. : Алетейя, 2000. — 466 с.

Lawrynenko 1962 - Lawrynenko J. Šev čenko and Kobzar in the intellectual and political history of a century / Jurij Lawrynenko // Taras Ševčenko 1814-1861; a symposium, edited by V. Mijakovskyj and G. Shevelov. - Hague, Mouton, 1962. Р. 153-258. - переклад у тексті мій. 